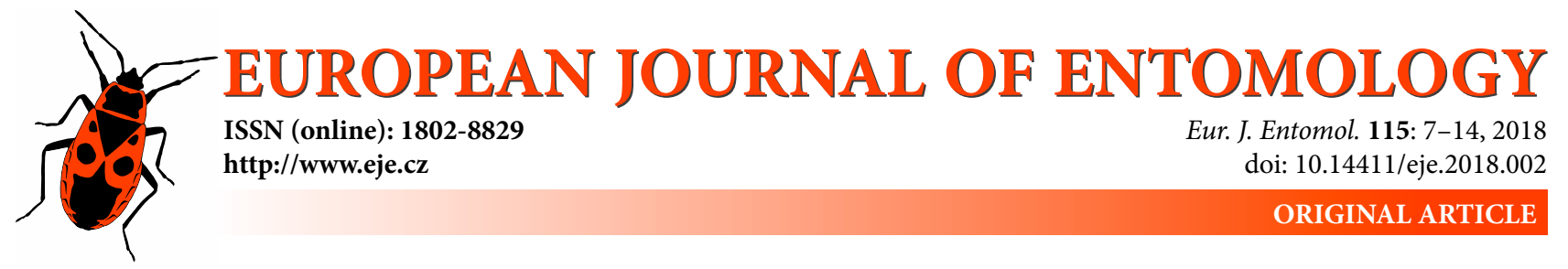

\title{
Genetic structure of populations of Aphis gossypii (Hemiptera: Aphididae) on citrus trees in Northern Iran
}

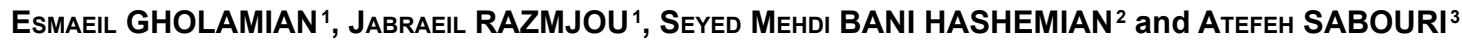

\begin{abstract}
${ }^{1}$ Department of Plant Protection, Faculty of Agriculture and Natural Resources, University of Mohaghegh Ardabili, Ardabil, Iran; e-mails: esm1351@yahoo.com, razmjou@uma.ac.ir

${ }^{2}$ Citrus and Subtropical Fruits Research Center, Horticultural Science Research Institute, Agricultural Research, Education and Extension Organization, 46915-335, Ramsar, Iran; e-mail: m.banihashemian@areo.ac.ir

${ }^{3}$ Department of Agronomy \& Plant Breeding, Faculty of Agricultural Sciences, University of Guilan, Rasht, Iran; e-mail: a.sabouri@guilan.ac.ir
\end{abstract}

\begin{abstract}
Key words. Hemiptera, Aphididae, Aphis gossypii, microsatellite, genetic differentiation, aphid, genotypic diversity, obligate parthenogenesis, Iran
\end{abstract}

\begin{abstract}
The cotton aphid, Aphis gossypii Glover (Hemiptera: Aphididae), is a serious pest of citrus in northern Iran, both because of the damaged caused by its feeding and as a vector of several viruses. The genetic structure of populations of $A$. gossypii on citrus trees at eight localities in Iran was surveyed using seven polymorphic microsatellite loci. Of 240 individuals tested, 142 multilocus genotypes (MLGs) were identified. The presence of multicopy genotypes and negative $F_{\text {IS }}$ values revealed that the major mode of reproduction in northern Iran is obligate parthenogenesis. The genotypic diversity of populations ranged between 0.24 and 0.93 . Considerable genotypic diversity and a high frequency of unique MLGs, confirmed there is some cyclical parthenogenesis in the region. The analysis of molecular variance revealed high intrapopulation and weak interpopulation genetic differentiation (overall $F_{\mathrm{ST}}=0.036$ ) among the different populations. The UPGMA dendrogram of eight populations based on Nei's genetic distance indicated two clusters: genotypes from West of Mazandaran and Guilan provinces and those from East of Mazandaran. The same results were also obtained from the STRUCTURE analysis of these populations. This information on the genetic diversity of populations of $A$. gossypii in northern Iran could be useful for improving the Integrated Pest Management of this aphid.
\end{abstract}

\section{INTRODUCTION}

During the last four decades, the use of molecular markers has provided new information about the biology of aphids including their phylogeny, life-cycles, host-plants and geographical dispersal. The greatest contribution of these markers has been in the genetic differentiation among and between populations (Loxdale \& Lushai, 2007; Loxdale et al., 2017). Generally, aphids have two modes of reproduction: obligate parthenogenesis and cyclical parthenogenesis with a single sexual generation that produces the over-wintering diapausing eggs (Dixon, 1998). However, some species of aphids have only one overwintering strategy and others overwinter both anholocyclically and holocyclically (Dedryver et al., 1998).

The cotton-melon aphid, Aphis gossypii Glover (Hemiptera: Aphididae), is a cosmopolitan species distributed worldwide (van Emden \& Harrington, 2007). It is an important pest of various plant families, such as Rutaceae, Cucurbitaceae, Malvaceae, Solanaceae and Rosaceae (Ebert \& Cartwright, 1997; Razmjou et al., 2006). It causes direct damage by feeding on sap and excreting honeydew and also indirect damage by transmitting several pathogen- ic plant viruses (Bertolini et al., 2000; Wang et al., 2016). There are two major citrus growing areas in Iran: (i) The northern part includes the Mazandaran and Guilan provinces in the Caspian Sea belt with a Mediterranean climate and periodically cold winters. These two provinces produce about $50 \%$ of the citrus fruit in Iran; (ii) The provinces in the southern region have tropical and subtropical climates (Bani Hashemian et al., 2013). A. gossypii is a serious pest of citrus orchards in northern Iran (Rassoulian et al., 2001), with cotton, cucumber, pumpkin and hibiscus as the other hosts of this aphid (Razmjou et al., 2010; Kheyrollahi et al., 2013). Moreover, it is a vector of Citrus tristeza virus, the most important viral pathogen of citrus (Moreno et al., 2008), in the region (Alavi et al., 2000). Citrus yellow vein clearing virus and Citrus vein enation virus were also recently reported in this area (Nouri et al., 2016; Bani Hashemian \& Aghajanzadeh, 2017). These pathogens can be transmitted by $A$. gossypii (Vives et al., 2013; Zhou et al., 2015). There are many diverse kinds of natural enemies in the citrus orchards of northern Iran, so little insecticide is used to control aphids in this region (Aghajanzadeh et al., 1997). 


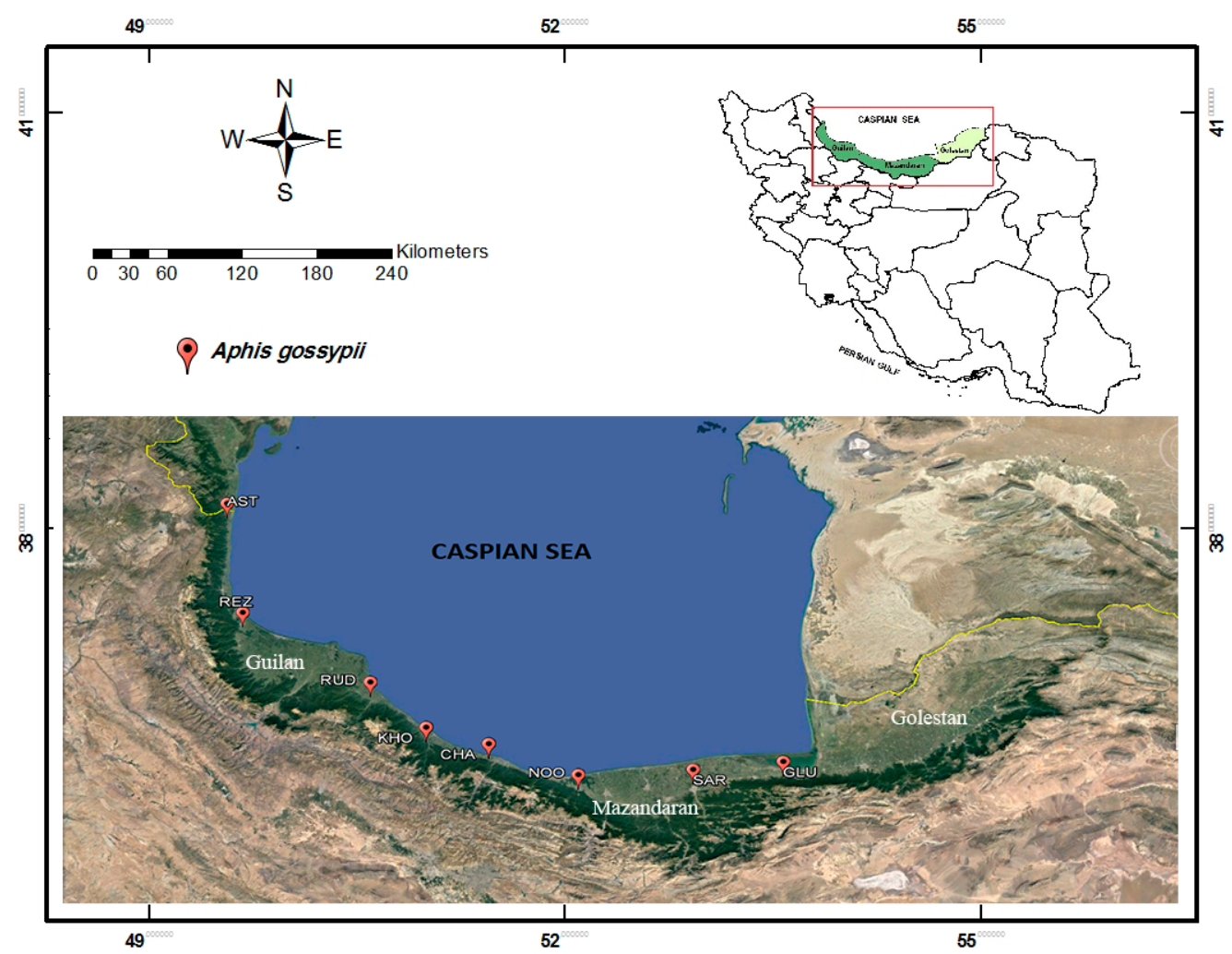

Fig. 1. Maps of Iran (above) and the Caspian Sea region (below) showing the locations where Aphis gossypii were collected. Population codes are the same as in Table 1.

The great diversity in the life cycles, host plants and geographical range of aphids makes them excellent models for research into these and many other aspects of their biology (Loxdale \& Balog, 2018), including their genetics (Blackman \& Eastop, 2007).

The genetic variation of aphid populations can certainly be affected by host plant. The relationship between the genetic diversity of $A$. gossypii and different host plants has been revealed by the use of polymorphic microsatellite markers, which indicate that one of three predominant multilocus genotypes is associated with each of the three plant families, Cucurbitaceae, Solanaceae and Rutaceae (Charaabi et al., 2008; Carletto et al., 2009). Further examples of such host plant-genetic diversity correlations are reported for other species of pest aphid, like the grain aphid, Sitobion avenae (F.) on wheat and cocksfoot grass (Sunnucks et al., 1997) and different grasses and cereals. (Lushai et al., 2002).

According to Delmotte et al. (2002), the genetic structure of sexual and asexual populations of the bird cherryoat aphid, Rhopalosiphum padi (L.), based on microsatellite data, reveals a high level of heterozygoty in asexual populations and variations in the life cycle of the black bean aphid, Aphis fabae Scopoli, associated with particular climatic conditions (Sandrock et al., 2011). In the case of A. gossypii populations in greenhouses in southern France, use of seven microsatellite loci has revealed they are mainly asexual (Fuller et al., 1999).

Genetic differences between aphid populations from different localities is also reported. For example, variation in microsatellite markers is a useful tool for genomic characterization of the soybean aphid, Aphis glycines Matsumura and the cabbage aphid, Brevicoryne brassicae (L.) from different geographic regions (Ruiz-Montoya et al., 2003; Michel et al., 2009; Jun et al., 2011). In addition, the genetic structure of populations of the Spirea aphid, Aphis spiraecola Patch on pear trees in 13 provinces in China has revealed high levels of genetic exchange facilitated by geography and climate (Cao et al., 2012). In other similar studies, molecular markers are used to demonstrate migration and dispersal in several other pest species of aphids (Delmotte et al., 2002; Llewellyn et al., 2003; Lushai \& Loxdale, 2004).

In the present study, a suite of polymorphic microsatellite markers was used to study the genetic diversity and genetic structure within and among populations and thereby deduce the life cycle of the $A$. gossypii that infest citrus trees in the north of Iran.

\section{MATERIAL AND METHODS}

\section{Sample collection}

Aphid samples were collected from different commercial citrus orchards at eight locations in the Guilan and Mazandaran provinces in northern Iran (Fig. 1). Thirty individuals were collected within an area of approximately $10 \mathrm{~km}^{2}$ at each location in 2015 and 2016 (Table 1). Aphids from a single tree were considered as one sample and only one aphid per sample was analyzed. Aphids were taken from trees that were at least $50 \mathrm{~m}$ apart from each other and the distance between any two populations was $>50 \mathrm{~km}$. Aphids were stored in micro tubes in $75 \%$ ethanol at $20^{\circ} \mathrm{C}$ prior to DNA extraction. 


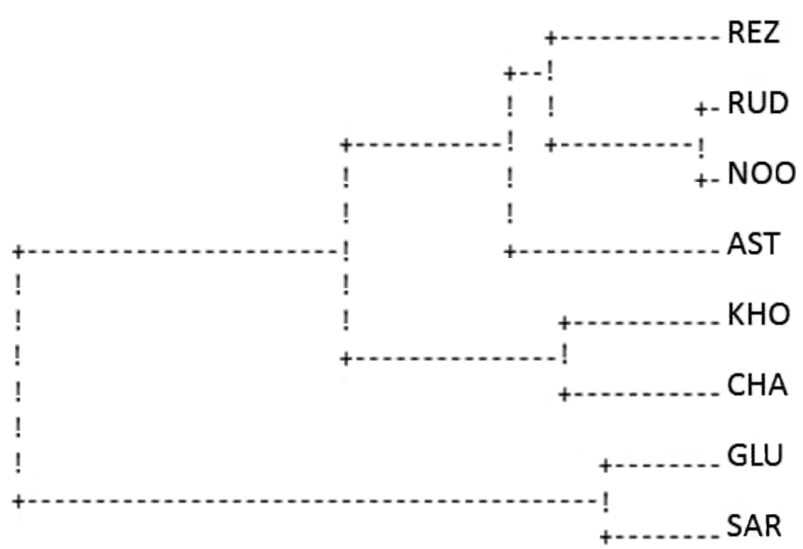

Fig. 2. UPGMA dendrogram based on Nei's genetic distance (1978) showing a clustering according to localities.

\section{DNA extraction and microsatellite analysis}

DNA was extracted from one aphid using the cetyltrimethyl ammonium bromide (CTAB) protocol (Doyle \& Doyle, 1987) The DNA was diluted 10 -fold and stored at $-20^{\circ} \mathrm{C}$. PCR was performed using $10 \mu \mathrm{L}$ of the reaction mixture, containing $6 \mu \mathrm{L}$ of $2 \times$ PCR Master Mix (Jena BioScience GmbH, Jena, Germany), 1 $\mu \mathrm{L}(10 \mathrm{pM})$ of each forward and reverse primer (Ago89, Ago66, Ago24, Ago59, Ago53, Ago84, Ago69, Ago126) (VanlerbergheMasutti et al., 1999) and $1.5 \mu \mathrm{L}$ of aphid template DNA (approximately $10 \mathrm{ng}$ ), using the following cycling parameters: initial denaturation at $94^{\circ} \mathrm{C}$ for 5 min followed by 35 cycles of denaturation at $94^{\circ} \mathrm{C}$ for $1 \mathrm{~min}$, locus-specific annealing temperature 1 min according to Vanlerberghe-Masutti et al. (1999); and extension at $74^{\circ} \mathrm{C}$ for $30 \mathrm{~s}$, with a final extension at $74^{\circ} \mathrm{C}$ for $5 \mathrm{~min}$. Products were separated on $6 \%$ polyacrylamide urea gel at 75 W constant power (Bio-Rad Laboratories, Hercules, CA, USA). DNA fragments were visualized using ethidum bromide staining and documented using the UV DOC system (EBOX VX5/20, VilberLoumat, France). Allele sizes were determined by comparison with the standard DNA Ladders SM1203 and SM1153 (Fernentase, Waltham, MA, USA).

\section{Data analysis}

The GenClone v.2.0 program (Arnaud-Haond \& Belkhir, 2007) was used to identify different multilocus genotypes (MLG), calculate genotypic diversity $(R)$, defined as $(G-1) /(N-1)$, where

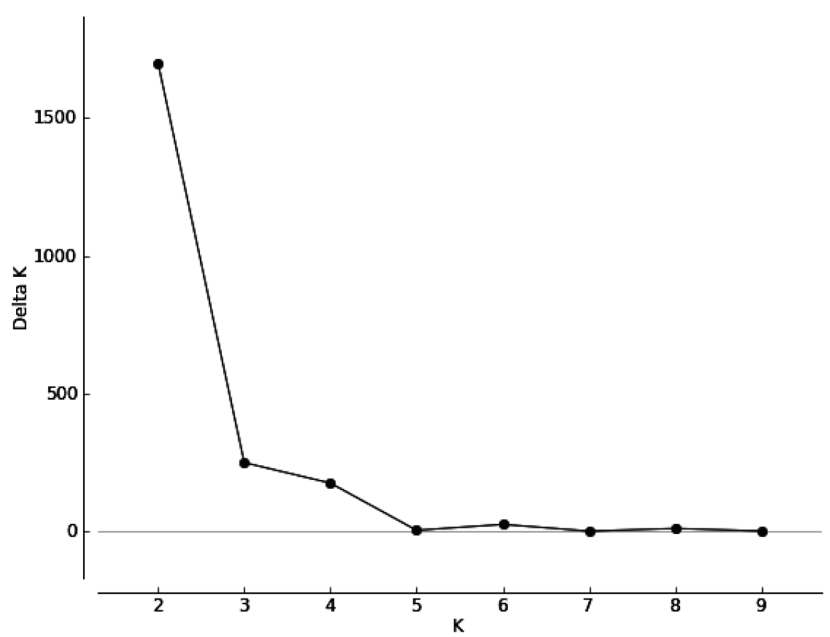

Fig. 3. $\Delta \mathrm{K}$ plot used to determine most probable $K$.

$G$ is the number of different MLGs and $N$ is the number of individuals in a population and $P_{s e x}$, the probability of replicate MLGs being produced by independent sexual events. Calculation of the number of alleles $\left(N_{q}\right)$, the effective number of alleles $\left(N_{e}\right), F$ statistics and Hardy-Weinberg Equilibria (HWE) was done using GENAlEX V 6.5 (Peakall \& Smouse, 2012). To analyze deviations from HWE, only a single representative of each multilocus genotype (MLG) was considered. Also, analysis of Molecular Variance (AMOVA) was calculated using this program in order to determine differences within and among populations. A Mantel test of isolation by distance (IBD) with 1,000 permutations was run in GENAlEX. MICRO-CHECKER software (van Oosterhout et al., 2004) was used to test for the possible occurrence of null alleles at the microsatellite loci tested. Genetic distance was calculated and a UPGMA dendrogram depicted using POPGENE 32 (Yeh et al., 1999).

STRUCTURE program version 2.3.4 (Pritchard et al., 2000) was used to infer the structure of the population and estimate the most likely number of distinct population clusters. The number of clusters $(K)$ considered was from 1 to 10 , and 5 replications with a burn-in length of 500,000 iterations and a Markov chain of 500,000 steps were executed. The most likely number of genetic clusters based on the log probability of the data was calculated using the method of Evanno et al. (2005).

Table 1. Summary of the information and genetic variability revealed by using seven microsatellite loci and Aphis gossypii collected from eight populations infesting citrus trees in northern Iran.

\begin{tabular}{|c|c|c|c|c|c|c|c|c|}
\hline $\begin{array}{l}\text { Sample collected } \\
\text { from }\end{array}$ & $\begin{array}{l}\text { Rezvanshahr - } \\
\text { Guilan }\end{array}$ & $\begin{array}{l}\text { Khoramabad - } \\
\text { Mazandaran }\end{array}$ & $\begin{array}{c}\text { Chaloss - } \\
\text { Mazandaran }\end{array}$ & $\begin{array}{l}\text { Rudsar - } \\
\text { Guilan }\end{array}$ & $\begin{array}{c}\text { Noor - } \\
\text { Mazandaran }\end{array}$ & $\begin{array}{c}\text { Sari - } \\
\text { Mazandaran }\end{array}$ & $\begin{array}{c}\text { Gluogah - } \\
\text { Mazandaran }\end{array}$ & $\begin{array}{l}\text { Astara - } \\
\text { Guilan }\end{array}$ \\
\hline Population code & REZ & $\mathrm{KHO}$ & $\mathrm{CHA}$ & RUD & $\mathrm{NOO}$ & SAR & GLU & AST \\
\hline Coordinates & $\begin{array}{c}37^{\circ} 31^{\prime} \mathrm{N} / \\
49^{\circ} 08^{\prime} \mathrm{F}\end{array}$ & $\begin{array}{c}36^{\circ} 45^{\prime} \mathrm{N} / \\
0^{\circ} 49^{\prime} \mathrm{F}\end{array}$ & $\begin{array}{l}36^{\circ} 40^{\prime} \mathrm{N} / \\
51^{\circ} 21^{\prime} \mathrm{F}\end{array}$ & $\begin{array}{l}37^{\circ} 04^{\prime} \mathrm{N} / \\
50^{\circ} 18^{\prime} \mathrm{F}\end{array}$ & $\begin{array}{l}36^{\circ} 29^{\prime} \mathrm{N} / \\
52^{\circ} 07^{\prime} \mathrm{F}\end{array}$ & $\begin{array}{c}36^{\circ} 36^{\prime} \mathrm{N} / \\
53^{\circ} 03^{\prime} \mathrm{F}\end{array}$ & $\begin{array}{l}36^{\circ} 43^{\prime} \mathrm{N} / \\
53^{\circ} 47^{\prime} \mathrm{F}\end{array}$ & $\begin{array}{c}38^{\circ} 23^{\prime} \mathrm{N} / \\
48^{\circ} 50^{\prime} \mathrm{F}\end{array}$ \\
\hline$N$ & 30 & $\begin{array}{l}049 \mathrm{E} \\
30\end{array}$ & $\begin{array}{c}5121 \mathrm{t} \\
30\end{array}$ & $\begin{array}{c}5018 \mathrm{t} \\
30\end{array}$ & 30 & $\begin{array}{c}5303 \mathrm{t} \\
30\end{array}$ & $\begin{array}{c}534 / \mathrm{E} \\
30\end{array}$ & $\begin{array}{c}4850 \mathrm{t} \\
30\end{array}$ \\
\hline G & 13 & 8 & 15 & 16 & 21 & 28 & 17 & 24 \\
\hline$R$ & 0.41 & 0.24 & 0.48 & 0.52 & 0.69 & 0.93 & 0.55 & 0.79 \\
\hline Repeated genotype & 9 & 6 & 5 & 5 & 5 & 1 & 4 & 5 \\
\hline Significant $P_{\text {sex }}$ & 5 & 5 & 3 & 4 & 3 & 0 & 2 & 2 \\
\hline$N_{a}$ & 3.86 & 2.86 & 4.00 & 4.14 & 4.29 & 4.71 & 3.90 & 4.86 \\
\hline$N_{e}^{d}$ & 3.17 & 2.31 & 2.61 & 3.01 & 3.16 & 3.18 & 2.82 & 3.14 \\
\hline$H_{0}$ & 0.91 & 0.82 & 0.93 & 0.88 & 0.88 & 0.85 & 0.87 & 0.83 \\
\hline$H_{e}$ & 0.66 & 0.57 & 0.63 & 0.65 & 0.66 & 0.67 & 0.66 & 0.66 \\
\hline$F_{\text {IS }}$ & -0.39 & -0.45 & -0.50 & -0.36 & -0.36 & -0.29 & -0.34 & -0.28 \\
\hline
\end{tabular}

$N$ - no. of individuals per pop; $G$ - multilocus genotype (clone sensu lato); $R$-clonal diversity; Repeated genotype - number of repeated genotypes per sample; Significant $P_{\text {sex }}$ - number of clonal genotypes; $N_{a}$ - observed no. of alleles per locus; $N_{e}-$ effective no. of alleles per locus; $H_{o}$ - observed heterozygosity; $H_{e}$ - expected heterozygosity; $F_{\text {IS }}-$ fixation index. 


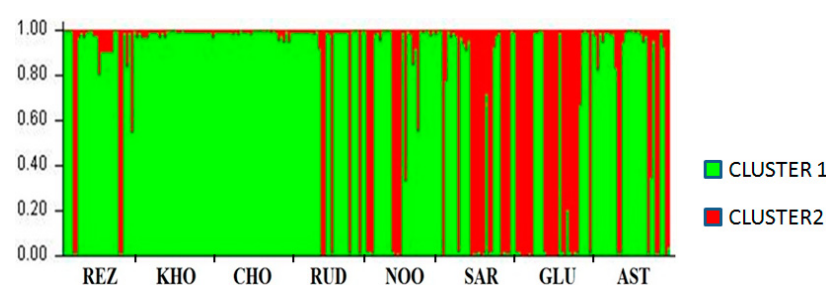

Fig. 4. Cluster analysis of the Aphis gossypii samples from northern Iran. Assignment of the multilocus genotypes of the 8 populations to clusters $(K=2)$. Each multilocus genotype is represented by a vertical bar. Geographic regions in which the populations were located are indicated along the $x$-axis.

\section{RESULTS}

\section{Genic and genotypic diversity}

Samples were genotyped using seven of the eight microsatellite primer pairs designed earlier by VanlerbergheMasutti et al. (1999). Locus Ago24 produced the same band pattern in all individuals and was hence excluded from the calculations. A total of 142 multilocus genotypes (MLGs) were distinguished in the 240 individuals. We refer to these as clones sensu lato (Loxdale, 2008). The number of MLGs ranged from 8 to 28 within each population. The lowest and highest genotypic diversity were recorded for KHO and SAR, respectively (Table 1). In the populations $\mathrm{KHO}, \mathrm{CHA}$ and REZ, the genotypic diversity was $\leq 0.5$.

Highly significant $P_{\text {sex }}$ values indicate that most of repeated genotypes in the samples were members of the same clone. However, the number of repeated genotypes were assembled independently by sexual reproduction (Table 1). The observed and effective number of alleles per locus for each population were 2.857-4.857 and 2.310-3.182, respectively (Table 1$)$. The observed $\left(H_{o}\right)$ and expected $\left(H_{e}\right)$ heterozygosity values ranged from $0.82-0.93$ and from 0.57-0.67, respectively (Table 1). Comparison of the $H_{0}$ and $H_{e}$ values for the 8 populations of $A$. gossypii revealed that $H_{o}$ values in all populations were greater than their $H_{e}$ values. The $F_{\text {IS }}$ values of -0.28 to -0.50 indicate excess heterozygosity, which is reflected in the negative values for the overall $F_{\text {IS }}$ (Table 1).

\section{Genetic differentiation among populations}

The AMOVA analyses revealed that $3 \%$ of the genetic variation was among populations and $97 \%$ within individuals (Table 4). This signifies that the genetic differentiation among populations (overall $F_{\mathrm{ST}}=0.036$ ) is less than within

Table 2. Nei's unbiased genetic distance measures among eight populations of Aphis gossypii collected from citrus trees in northern Iran.

\begin{tabular}{lcccccccc}
\hline Pop & REZ & KHO & CHA & RUD & NOO & SAR & GLU & AST \\
\hline REZ & $* * * *$ & & & & & & \\
KHO & 0.0484 & $* * * *$ & & & & & \\
CHA & 0.0603 & 0.0254 & $* * * *$ & & & & & \\
RUD & 0.0302 & 0.0779 & 0.0152 & $* * * *$ & & & \\
NOO & 0.0342 & 0.1324 & 0.0731 & 0.0012 & $* * * *$ & & \\
SAR & 0.0321 & 0.2031 & 0.0164 & 0.0668 & 0.0562 & $* * * *$ & & \\
GLU & 0.0398 & 0.1683 & 0.1243 & 0.0340 & 0.0220 & 0.0199 & $* * * *$ \\
AST & 0.0420 & 0.1046 & 0.0714 & 0.0541 & 0.0215 & 0.0490 & 0.0476 & $* * * *$ \\
\hline
\end{tabular}

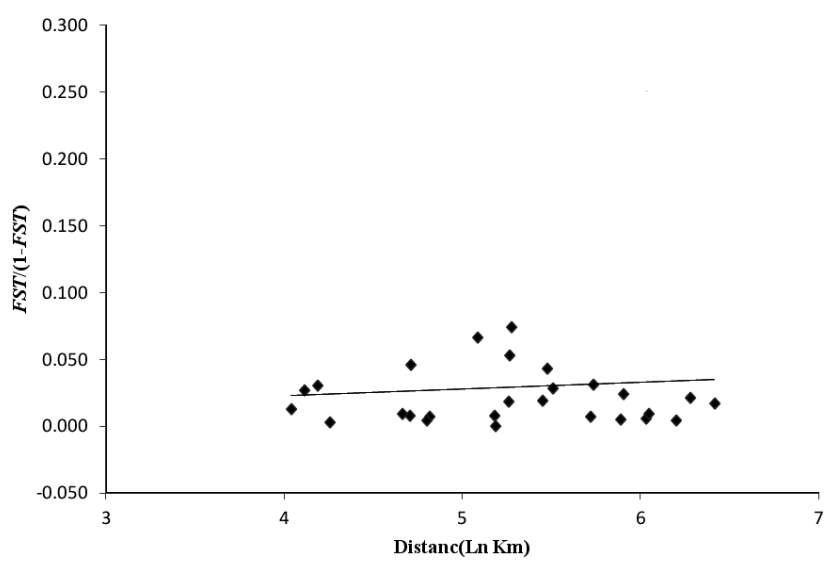

Fig. 5. Isolation-by-distance plot of $F_{\mathrm{ST}} /\left(1-F_{\mathrm{ST}}\right)$ plotted against the natural logarithm of geographical distance $(\mathrm{km})$ for all of the 8 geographically separated populations.

populations. Most of the genetic differentiation among the 8 populations of $A$. gossypii were not significant based on the matrix of pairwise $F_{\mathrm{ST}}$ values (Table 3 ). $F_{\mathrm{ST}}$ values showed a weak genetic structuring, while only 3 of 28 pairwise comparisons exceeded 0.05 (Table 3 ).

According to the IBD analysis, there was no significant correlation between linearized $F_{\mathrm{ST}}$ and geographic distance ( $r=0.072$., $P=0.71$; Fig. 5 ) for the 8 populations. The minimum and maximum genetic distances were between the NOO and RUD populations (0.0012), and KHO and SAR populations (0.2031), respectively (Table 2$)$. The UPGMA dendrogram of the 8 populations based on Nei's genetic distance is depicted in Fig. 2. The GLU and SAR populations from East of Mazandaran clustered together and populations from the rest of Mazandaran (NOO, CHA and KHO) and Guilan (RUD, REZ and AST) were in another cluster.

The STRUCTURE analysis of $A$. gossypii populations estimated the log-likelihoods and the number of genetic clusters $(K)$ (Evanno et al., 2005) (Fig. 3). These results indicate that the 8 populations group in two clusters: $97.08 \%$ of individuals could be assigned to one of the clusters with more than $80 \%$ probability and $2.92 \%$ were considered to be admixed with $K=2$ (Fig. 4). Most genotypes collected from SAR and GLU were placed in cluster 1, while all genotypes from $\mathrm{KHO}$ and $\mathrm{CHA}$, and most of those from the other localities were assigned to cluster 2 (Fig. 4).

Table 3. Pairwise $F_{\mathrm{ST}}$ values among the eight populations of Aphis gossypii collected from citrus trees in northern Iran.

\begin{tabular}{|c|c|c|c|c|c|c|c|}
\hline Pop & REZ & $\mathrm{KHO}$ & $\mathrm{CHA}$ & RUD & $\mathrm{NOO}$ & SAR & GLU AST \\
\hline REZ & $* * * *$ & & & & & & \\
\hline $\mathrm{KHO}$ & $0.018 \mathrm{~ns}$ & $* * * *$ & & & & & \\
\hline $\mathrm{CHA}$ & $0.028 \mathrm{~ns}$ & $0.013 \mathrm{~ns}$ & $* * * *$ & & & & \\
\hline RUD & $0.007 \mathrm{~ns}$ & $0.030 \mathrm{~ns}$ & $0.004 \mathrm{~ns}$ & $* * * *$ & & & \\
\hline $\mathrm{NOO}$ & $0.007 \mathrm{~ns}$ & $0.046 \mathrm{~ns}$ & $0.027 \mathrm{~ns}$ & $0.000 \mathrm{~ns}$ & $* * * *$ & & \\
\hline SAR & $0.006 \mathrm{~ns}$ & $0.074^{\star *}$ & $0.066^{*}$ & $0.024^{*}$ & $0.008 \mathrm{~ns}$ & $* * * *$ & \\
\hline GLU & $0.004 \mathrm{~ns}$ & $0.053^{*}$ & $0.043^{*}$ & $0.005 \mathrm{~ns}$ & $0.008 n s$ & $0.003 n s$ & $* * * *$ \\
\hline AST & $0.009 \mathrm{~ns}$ & $0.031 \mathrm{~ns}$ & $0.024 \mathrm{~ns}$ & $0.019 \mathrm{~ns}$ & $0.009 n s$ & $0.021^{*}$ & $0.017 \mathrm{~ns}^{* * * *}$ \\
\hline
\end{tabular}


Table 4. Analysis of molecular variance used to compare the genetic variation in populations of Aphis gossypii, collected from citrus trees in northern Iran.

\begin{tabular}{lccccc}
\hline Source of variation & d.f. & Sum of squares & Variance components & Percentage of variation & $\mathrm{P}$ Value \\
\hline (A) Among geographic populations & 7 & 50.258 & 0.098 & $3 \%$ & $\mathrm{P}<0.001$ \\
Within individuals & 240 & 765.000 & 3.188 & $97 \%$ & $\mathrm{P}<0.001$ \\
(B) Among 2 clusters inferred by STRUCTURE & 1 & 93.300 & 0.529 & $14 \%$ & $\mathrm{P}<0.001$ \\
Within individuals & 233 & 745.000 & 3.197 & $86 \%$ & $\mathrm{P}<0.001$ \\
\hline
\end{tabular}

(A) Populations collected from citrus trees; (B) Two clusters according to Bayesian analysis.

\section{DISCUSSION}

In the present study, the genetic structure of populations of the aphid, A. gossypii, collected from citrus orchards at different localities in the Caspian Sea region of Iran was analyzed. The presence of multicopy genotypes, highly significant $P_{\text {sex }}$ values in repeated genotypes and negative $F_{\text {IS }}$ values indicate that this aphid reproduces mainly by obligate parthenogenesis in the northern part of Iran (Table 1). A. gossypii is an obligate parthenogen in most parts of the world (Blackman \& Eastop, 2000), but in some regions like North America, East Asia and China there are populations that are cyclically parthenogenetic (Zhang \& Zhong, 1982; Blackman \& Eastop, 2007). Previous investigations on the genetic diversity of populations of $A$. gossypii using eight microsatellite loci also indicate asexual reproduction, based on the nonrecombinant genotypes present in the populations (Fuller et al., 1999; Brévault et al., 2008; Charaabi et al., 2008; Chen et al., 2013). The same results are also reported for other species of pest aphids (e.g. Sunnucks et al., 1996; Miller et al., 2003; Vorburger et al., 2003; Vorwerk \& Forneck, 2006; Aradottir et al., 2012).

Although we detected a clear genetic signature of clonal reproduction, existence of 142 different multilocus genotypes among the individuals and the number of non-significant $P_{\text {sex }}$ values in single population indicate that some of the clones of this aphid in this region reproduced sexually (Table 1). Cyclical parthenogenesis can result in more genotypic diversity in populations of this aphid (Simon et al., 1996; Delmotte et al., 2002; Wilson et al., 2002; Cao et al., 2012). Razmjou et al. (2010) report that samples of $A$. gossypii from cotton in the Caspian Sea region of Iran have a high genotypic diversity and many lineages on this host are cyclically parthenogenetic. A recent study in northern China showed considerable genotypic diversity among $A$. gossypii populations on cotton (Luo et al., 2016). Such studies are very valuable because they can be used to indirectly infer the type of life-cycle of an aphid (Le Trionnaire et al., 2008).

Whether or not aphids reproduce sexually or asexually depends on the winter climate (Rispe \& Pierre, 1998). Sandrock et al. (2011) show that life cycle variation in the black bean aphid, A. fabae, is related to climate and aphids from areas with mild winters overwinter anholocyclically more than those from areas with cold winters. A mild winter in the Caspian Sea belt enables A. gossypii to overwinter parthenogenetically. Nevertheless, the occurrence of periodical cold winters seemingly induces some cyclical parthenogenesis and production of overwintering eggs in this region. When winters are cold, overwintering as sexu- ally produced eggs is a dependable strategy because eggs in diapause are very cold-resistant (James \& Luff, 1982; Rispe \& Pierre, 1998; Simon et al., 1999).

Application of broad-range insecticides to host plants to control a pest can decrease the number of genotypes. In West and Central Africa, the increased use of insecticides on both cotton and other host plants (okra and roselle) has led to the prevalence of one genotype of A. gossypii resistant to different classes of insecticides (Brévault et al., 2011). In the Caspian Sea region, insecticides are rarely used to control citrus aphids, so the presence of many aphid genotypes is expected.

Results of the IBD analysis revealed that geographic distance had no effect on $A$. gossypii population structure. The AMOVA analysis identified a low level of population differentiation (Global $F_{\mathrm{ST}}=0.036$ ) among populations of A. gossypii from citrus trees in northern Iran. Low genetic differentiation of $A$. gossypii was also indicated by both the UPGMA dendrogram based on Nei's genetic distance and the STRUCTURE analysis. These high intrapopulation and weak interpopulation genetic diversity patterns may reflect significant gene flow among populations. The amount of gene flow based on the $F_{\mathrm{ST}}$ values support such a scenario. However, $N_{m}$ (number of migrants) values varied greatly, ranging from 3.11 to 89.03 (data not shown). Our results are in agreement with the findings that low genetic differentiation confirms high gene flow. Little genetic differentiation among bird cherry-oat aphid ( $R$. padi) populations in France, indicate extensive gene flow, at least over short distances (Delmotte et al., 2002). In a study on the peach-potato aphid, Myzus persicae (Sulzer) in Victoria, Australia, the low overall $F_{\mathrm{ST}}$ value recorded and the widespread occurrence of the two most common genotypes provided evidence that individuals of this aphid move relatively freely in that region (Vorburger et al., 2003).

In northern Iran, citrus orchards are situated along the Caspian Sea belt where there are no geographical barriers so aphids can move easily across this region. As a consequence, the lack of complete genetic separation of populations in this area is a reasonable deduction from our data. Aphids can migrate over long distances (Simon et al., 1999; Llewellyn et al., 2003), although, short-distance movements are generally more important for the distribution of genotypes in aphid populations (Loxdale et al., 1993). The genetic structure of $A$. gossypii collected from six localities in Tunisia confirmed that genetic differentiation among localities was not statistically significant (Charaabi et al., 2008), whilst a study of the genetic structure of sexual French populations of $R$. padi showed little geographical 
differentiation among them, confirming the high dispersal ability of this aphid (Delmotte et al., 2002).

Based on the results of the STRUCTURE analysis, the SAR and GLU populations were grouped in one cluster and the other populations in another. The AMOVA also detected significant differences between these two clusters (Table 4). The east of Mazandaran, which includes the SAR and GLU populations has colder winters, warmer summers and less rainfall compared to other parts of the Caspian Sea region (Pirnia et al., 2015). Also, there are alternate hosts for A. gossypii there. The aphids on these hosts can also colonize citrus trees. So, the genetic differences between the two clusters may due to the above reasons. Further studies are required to determine the importance of these various factors. According to Cao et al. (2012), differences in climate in different regions should be considered when attempting to understand the population structure of $A$. spiraecola.

In conclusion, there is considerable genotypic diversity and high intrapopulation and weak interpopulation genetic differentiation among geographic populations of $A$. gossypii in northern Iran. Furthermore, A. gossypii on citrus, reproduces predominantly by obligate parthenogenesis in northern Iran. As indicated by this study and other studies on different species of aphids, assessment of population genetic diversity can be used in Integrated Pest Management and the findings used to develop more rational and sustainable methods of control. Lastly, based on the information gained during this research, it appears likely that further projects can be developed to study the relationship between the aphid's genotype and virus transmission, such as that done earlier for $M$. persicae by Terrodot et al. (1999).

ACKNOWLEDGEMENTS. A part of this work was supported by the Citrus and Subtropical Fruits Research Center (CSRC). Also, the work was partially funded by the University of Mohaghegh Ardabili, Iran. The authors would like to thank C. Vorburger for valuable comments and suggestions and H. Taheri (CSRC) for helpful comments and software analysis.

\section{REFERENCES}

Aghajanzadeh S., Rasoulian G.H., Rezvani N. \& Esmaili M. 1997: Study on faunistic aspects of citrus aphids in WestMazandaran. - Entomol. Phytopathol. 65: 62-78 [in Persian, English abstr.].

Alavi V., Rahimian H. \& Izadpanah K. 2000: Detection of Citrus tristeza virus by direct and indirect ELISA and dot immunobinding assay. In: Proc. of the 14th Iranian Plant Protection Congress. p. 133 [in Persian, English abstr].

Aradottir G.I., Hanley S.J., Collins C., Dawson K.J., Karp A., Leather S.R., Shield I. \& Harrington R. 2012: Population genetics of Tuberolachnus salignus, an obligate parthenogenetic aphid. - Agr. Forest Entomol. 14: 197-205.

Arnaud-HaOnd S. \& BelKhiR K. 2007: GENCLONE: a computer program to analyse genotypic data, test for clonality and describe spatial clonal organization. - Mol. Ecol. Notes 7: $15-17$.

Bani Hashemian S.M. \& Aghajanzadeh S. 2017: Occurrence of Citrus yellow vein clearing virus in citrus species in Iran. $-J$. Plant Pathol. 99: 290.
Bani Hashemian S.M., Taheri H., Mohammad Alian Y., Bové J.M. \& Duran-Vila N. 2013: Complex mixtures of viroids identified in the two main citrus growing areas of Iran. $-J$. Plant Pathol. 95: 647-654.

Bertolini E., Moreno A., Capote N., Olmos A., de Luis A., Vidal E., Pérez-Panadés J. \& Blackman R.L. \& Eastop V.F. 2000: Aphids on the World's Crops: An Identification and Information Guide. John Wiley and Sons, Chichester, $414 \mathrm{pp}$.

BLACKMAN R.L. \& EASTOP V.F. 2000: Aphids on the World's Crops: An Identification and Information Guide. John Wiley and Sons, Chichester, 414 pp.

Blackman R.L. \& Eastop V.F. 2007: Aphids on the World's Herbaceous Plants and Shrubs: An Identification and Information Guide. John Wiley and Sons, Chichester, 466 pp.

Brévault T., Carletto J., Linderme D. \& Vanlerberghe-Masutті F. 2008: Genetic diversity of the cotton aphid Aphis gossypii in the unstable environment of a cotton growing area. - Agr. Forest Entomol. 10: 215-223.

Brévault T., Carletto J., Tribot J. \& Vanlerberghe-Masutti F. 2011: Insecticide use and competition shape the genetic diversity of the aphid Aphis gossypii in a cotton-growing landscape. - Bull. Entomol. Res. 101: 407-413.

Cao J., Li J., Niu J., Liu X. \& Zhang Q. 2012: Population structure of Aphis spiraecola (Hemiptera: Aphididae) on pear trees in China identified using microsatellites. - J. Econ. Entomol. 105: 583-591.

Carletto J., Lombaert E., Chavigny P., Brevault T., Lapchin L. \& VANLerberghe-Masutti F. 2009: Ecological specialization of the aphid Aphis gossypii Glover on cultivated host plants. Mol. Ecol. 18: 2198-2212.

Charaabi K., Carletto J., Chavigny P., Marrakchi M., Makni M. \& VAnLerberghe-Masutti F. 2008: Genotypic diversity of the cotton-melon aphid Aphis gossypii (Glover) in Tunisia is structured by host plants. - Bull. Entomol. Res. 98: 333-341.

Chen Y., Vanlerberghe-Masutti F., Wilson L.J., Barchia I., McLoon M.O., Smith T. \& Herron G.A. 2013: Evidence of superclones in Australian cotton aphid Aphis gossypii Glover (Aphididae: Hemiptera). — Pest Manag. Sci. 69: 938-948.

Dedryver C.A., Le Gallic J.F., Gauthier J.P. \& Simon J.C. 1998: Life cycle of the cereal aphid Sitobion avenae, polymorphism and comparison of life history traits associated with sexuality. - Ecol. Entomol. 23: 123-132.

Delmotte F., Leterme N., Gauthier J.P., Rispe C. \& Simon J.C. 2002: Genetic architecture of sexual and asexual populations of the aphid Rhopalosiphum padi based on allozyme and microsatellite markers. - Mol. Ecol. 11: 711-723.

Dixon A.F.G. 1998: Aphid Ecology, 2nd ed. Chapman \& Hall, London, $312 \mathrm{pp}$.

Doyle J.J. \& DoyLe J.L. 1987: A rapid DNA isolation procedure for small quantities of fresh leaf tissue. - Phytochem. Bull. 19: $11-15$.

EBert T.A. \& CARTwright B. 1997: Biology and ecology of Aphis gossypii Glover (Homoptera: Aphididae). — Southw. Entomol. 22: 116-153.

Evanno G., Regnaut S. \& Goudet J. 2005: Detecting the number of clusters of individuals using the software STRUCTURE: a simulation study. - Mol. Ecol. 14: 2611-2620.

Fuller S.J., Chavigny P., Lapchin L. \& Vanlerberghehe-MasSUTTI F. 1999: Variation in clonal diversity in glasshouse infestations of the aphid, Aphis gossypii Glover in southern France. - Mol. Ecol. 8: 1867-1877.

JAMES B.D. \& LufF M.L. 1982: Cold-hardiness and development of eggs of Rhopalosiphum insertum. - Ecol. Entomol. 7: 277-282. 
Jun T.H., Michel A.P. \& Mian M.R. 2011: Development of soybean aphid genomic SSR markers using next generation sequencing. - Genome 54: 360-367.

Kheyrollahi Z., Hosseini R., Aghajanzadeh S. \& Golein B. 2013: Genetic variation of Aphis gossypii Glover (Hemiptera: Aphididae) in eastern Guilan and western Mazandaran provinces (Iran). - Plant Pest Res. 3: 11-19 [in Persian, English abstr.].

Le Trionnaire G., Hardie J., Jaubert-Possamai S., Simon J.C. \& TAGU D. 2008: Shifting from clonal to sexual reproduction in aphids: physiological and developmental aspects. - Biol. Cell 100: 441-451.

Llewellyn K.S., Loxdale H.S., Harrington R., Brookes C.P., Clarke S.J. \& Sunnucks P. 2003: Migration and genetic structure of the grain aphid (Sitobion avenae) in Britain related to climate and clonal fluctuation as revealed using microsatellites. - Mol. Ecol. 12: 21-34.

LOXDALE H.D. 2008: The nature and reality of the aphid clone - genetic variation, adaptation and evolution. - Agr. For. Entomol. 10: 81-90.

LoXdale H.D. \& BAlog A. 2018: Aphid specialism as an example of ecological-evolutionary divergence. - Biol. Rev. 93: 642-657.

Loxdale H.D. \& Lushai G. 2007: Population genetic issues: the unfolding story using molecular markers. In van Emden H.F. \& Harrington R. (eds): Aphids as Crop Pests. CABI, Wallingford, pp. 31-67.

Loxdale H.D., Hardie J., Halbert S., Foottit R., Kidd N.A.C. \& CARTER C.I. 1993: The relative importance of short- and longrange movement of flying aphids. - Biol. Rev. 68: 291-311.

Loxdale H.D., Edwards O., Tagu D. \& Vorburger C. 2017: Population genetic issues: new insights using conventional molecular markers and genomics tools. In van Emden H.F. \& Harrington R. (eds): Aphids as Crop Pests. 2nd ed. CABI, Wallingford, pp. 50-80.

Luo J.Y., Zhang S., Wang L., Lv L.M., Wang C.Y., Li C.H., Zhu X.Z., Zноu Z.G. \& Cur J.J. 2016: The distribution and host shifts of cotton-melon aphids in northern China. - PLOS ONE 11(3): e0152103, $15 \mathrm{pp}$.

Lushai G. \& Loxdale H.D. 2004: Tracking movement in small insect pests, with special reference to aphid populations. - Int J. Pest Manag. 50: 307-315.

Lushai G., Markovitch O. \& Loxdale H.D. 2002: Host-based genotype variation in insects revisited. - Bull. Entomol. Res. 92: 159-164.

Michel A.P., Zhang W., Jung J.K., Kang S.T. \& Mian M.A.R. 2009: Population genetic structure of Aphis glycines. - Environ. Entomol. 38: 1301-1311.

Miller N.J., Birley A.J., Overall A.D.J. \& Tatchell G.M. 2003: Population genetic structure of the lettuce root aphid, Pemphigus bursarius (L.), in relation to geographic distance, gene flow and host plant usage. - Heredity 91: 217-223.

Moreno P., Ambrós S., Albiach-Martí M.R., Guerri J. \& Peña L. 2008: Citrus tristeza virus: a pathogen that changed the course of the citrus industry. - Mol. Plant Pathol. 9: 251-268.

NEI M. 1978: Estimation of average heterozygosity and genetic distance from a small number of individuals. - Genetics $\mathbf{8 9}$ : 583-590.

Nouri S., Dizadji A. \& Rahimian H. 2016: Preliminary study of the distribution of Citrus vein enation virus in some citrus growing provinces of Iran and determination of appropriate times for virus detection. In: Proc. of the 22nd Iranian Plant Protection Congress. pp. 27-30 [in Persian, English abstr].
Peakall R. \& Smouse P.E. 2012: GenAlEx 6.5, genetic analysis in Excel. Population genetic software for teaching and research - an update. - Bioinformatics 28: 2537-2539.

Pirnia A., Habibnejad Roshan M. \& Solaimani K. 2015: Investigation of precipitation and temperature changes in Caspian sea southern coasts and its comparison with changes in northern hemisphere and global scales. - J. Watershed Manag. Res. 6: 90-100 [in Persian, English abstr.].

Pritchard J.K., Stephens M. \& Donnelly P. 2000: Inference of population structure using multilocus genotype data. - Genetics 155: 945-959.

Rassoulian G.H., Aghajanzadeh S., Rahimian H. \& Mosahebi G.H. 2001: Study of Citrus tristeza virus by major citrus aphids in Mazandaran. - Iran. J. Agr. Sci. 32: 585-589 [in Persian, English abstr.].

Razmjou J., Moharramipour S., Fathipour Y. \& Mirhoseini S.Z. 2006: Effect of cotton cultivar on performance of Aphis gossypii (Hom: Aphididae) in Iran. - J. Econ. Entomol. 99: $1820-1825$

Razmjou J., Vorburger C., Moharramipour S., Mirhoseini S. Z. \& FATHIPOUR Y. 2010: Host-associated differentiation and evidence for sexual reproduction in Iranian populations of the cotton aphid, Aphis gossypii. - Entomol. Exp. Appl. 134: 191-199.

Rispe C. \& Pierre J.S. 1998: Coexistence between cyclical parthenogens, obligate parthenogens, and intermediates in a fluctuating environment. $-J$. Theor. Biol. 195: 97-110.

Ruiz-Montoya L., Nunez-Farfan J. \& Vargas J. 2003: Host-associated genetic structure of Mexican populations of the cabbage aphid Brevicoryne brassicae L. (Homoptera: Aphididae). - Heredity 91: 415-421.

Sandrock C., Razmjou J. \& Vorburger C. 2011: Climate effects on life cycle variation and population genetic architecture of the black bean aphid, Aphis fabae. - Mol. Ecol. 20: 41654181.

Simon J.C., Carrel E., Hebert P.D.N., Dedryver C., Bonhomme A.J. \& GALLIC LE J.F. 1996: Genetic diversity and mode of reproduction in French populations of the aphid Rhopalosiphum padi L. - Heredity 76: 305-313.

Simon J.C., Baumann S., Sunnucks P., Hebert P.D.N., Pierre J.S., Le Gallic J.F. \& Dedryver C.A. 1999: Reproductive mode and population genetic structure of the cereal aphid Sitobion avenae studied using phenotypic and microsatellite markers. - Mol. Ecol. 8: 531-545.

Sunnucks P., England P., Taylor A.C. \& Hales D.F. 1996: Microsatellite and chromosome evolution of parthenogenetic Sitobion aphids in Australia. - Genetics 144: 747-756.

Sunnucks P., De Barro P.J., Lushai G., Maclean N. \& Hales D.F. 1997: Genetic structure of an aphid studied using microsatellites: cyclic parthenogenesis, differentiated lineages, and host specialization. - Mol. Ecol. 6: 1059-1073.

Terradot L., Simon J.C., Leterme N., Bourdin D., Wilson A.C.C., Gauthier J.P. \& Robert Y. 1999: Molecular characterization of clones of the Myzus persicae complex (Hemiptera: Aphididae) differing in their ability to transmit the potato leafroll luteovirus (PLRV). - Bull. Entomol. Res. 89: 355-363.

Vanlerberghe-Masutti F., Chavigny P. \& Fuller S.J. 1999: Characterisation of microsatellite loci in the aphid, Aphis gossypii Glover. - Mol. Ecol. 8: 693-695.

VAn Emden H.F. \& Harrington R. 2007: Aphids as Crop Pests. CABI, Wallingford, $717 \mathrm{pp}$.

Van Oosterhout C., Hutchinson W.F., Wills D.P.M. \& Shipley P. 2004: MICRO-CHECKER: Software for identifying and correcting genotyping errors in microsatellite data. - Mol. Ecol. Notes 4: 535-538. 
Vives M.C., Velázquez K., Pina J.A., Moreno P., Guerri J. \& NAVARRo L. 2013: Identification of a new enamovirus associated with citrus vein enation disease by deep sequencing of small RNAs. - Phytopathology 103: 1077-1086.

Vorburger C., LANCASTer M. \& SunNucks P. 2003: Environmentally related patterns of reproductive modes in the aphid Myzus persicae and the predominance of two 'superclones' in Victoria, Australia. - Mol. Ecol. 12: 3493-3504.

VORWERK S. \& ForNeCK A. 2006: Reproductive mode of grape phylloxera (Daktulosphaira vitifoliae, Homoptera: Phylloxeridae) in Europe: molecular evidence for predominantly asexual populations and a lack of gene flow between them. - Genome 49: 678-687.

Wang L., Zhang S., Luo J.Y., Wang C.Y., Lv L.M., Zhu X.Z., Li C.H. \& CuI J.J. 2016: Identification of Aphis gossypii Glover (Hemiptera: Aphididae) biotypes from different host plants in North China. — PLOS ONE 11(1): e0146345, 15 pp.
Wilson A.C.C., Sunnucks P., Blackman R.L. \& Hales D.F. 2002: Microsatellite variation in cyclically parthenogenetic populations of Myzus persicae in south-eastern Australia. - Heredity 88: 258-266.

Yeh F.C., YAng R.C. \& Boyle T.B.J. 1999: POPGENE Ver. 1.31. Microsoft Window-based Freeware for Population Genetic Analysis. Quick User Guide. Molecular Biology and Biotechnology Center, University of Alberta, Edmonton, Canada.

ZhANG G.X. \& ZhoNG T.S. 1982: Experimental studies on some aphid life-cycle patterns. - Sinozoologia 2: 2-17.

Zhou Y., Chen H.M., Wang X.F., Li Z.A., Tang M. \& Zhou C.Y. 2015: Lack of evidence for seed transmission of Citrus yellow vein clearing virus despite its frequent detection in seed tissues. - J. Plant Pathol. 97: 1-3.

Received July 19, 2017; revised and accepted December 27, 2017 Published online January 29, 2018 